\title{
Corrosion Behavior of Commercial Aluminum Alloy Processed by Equal Channel Angular Pressing
}

\author{
Atef Korchef $^{1}$ and Abdelkrim Kahoul ${ }^{2}$ \\ ${ }^{1}$ National Center of Researches in Materials Sciences, Technopark of Borj-Cédria, BP 73, 8027 Soliman, Tunisia \\ ${ }^{2}$ Laboratoire d'Energétique et d'Electrochimie des Solides (LEES), Faculté de Technologie, Université Ferhat Abbas, \\ 19000 Sétif, Algeria
}

Correspondence should be addressed to Abdelkrim Kahoul; kahoulabdelkrim@yahoo.fr

Received 23 February 2013; Revised 16 May 2013; Accepted 23 May 2013

Academic Editor: W. Ke

Copyright (C) 2013 A. Korchef and A. Kahoul. This is an open access article distributed under the Creative Commons Attribution License, which permits unrestricted use, distribution, and reproduction in any medium, provided the original work is properly cited.

\begin{abstract}
A commercial aluminum alloy was subjected to severe plastic deformation through equal channel angular pressing (ECAP). The alloy contains a low volume fraction of $\alpha$-AlFeSi located essentially at the grain boundaries. The corrosion behavior of the ECAP'ed alloy was investigated in $\mathrm{NaCl}$ solution using potentiodynamic polarization and immersion tests. The effects of scan rate and $\mathrm{NaCl}$ concentration on the alloy susceptibility to corrosion were also studied. The results obtained were compared with those of the nonpressed alloy. ECAP leads to an intensive grain refinement accompanied by an increased dislocation density. All electrochemical tests confirm that corrosion resistance of the alloy remarkably diminished with increasing the ECAP number of passes. This is presumably due to the breakdown of the $\alpha$-AlFeSi after ECAP leading to higher number of galvanic cells and enhanced dissolution of the aluminum matrix.
\end{abstract}

\section{Introduction}

It is now well known that severe plastic deformation (SPD) leads to enhanced grain refinement to the submicrometer $(100-1000 \mathrm{~nm})$ or nanometer $(<100 \mathrm{~nm})$ levels. The intensive grain refinement is responsible for the enhancement of physical and mechanical properties of the processed materials, such as high strength and ductility. SPD techniques include, among others, torsion under high pressure [1], accumulative roll bonding (ARB) [2], and equal channel angular pressing (ECAP) $[3,4]$. The latter procedure, introduced almost 30 years ago to achieve enhanced plastic strains, is especially attractive for several near superplastic applications. Since the cross-section of the sample remains unchanged during ECAP, repetitive pressings on the same sample are possible to achieve the required strains and to invoke different slip systems by rotating differently the sample between consecutive passes [4]. Thus, the microstructure obtained after ECAP depends on the introduced strains and whether and how the sample is rotated between two successive passes. In the early stages of pressing, reported results in the literature showed that the microstructure was reasonably homogeneous and consisted of parallel bands of subgrains. For further pressings, these subgrains evolved into an array of refined grains separated by high angle boundaries [5]. As a result of the grain refinement, a significant improvement of the mechanical properties was observed after ECAP [6].

In addition, ECAP process alters the bulk of the material leading to changes in material flow, residual stress, texture, size and distribution of a second phase if any exists in the material, and so forth. In addition to grain refinement, these changes significantly affect the corrosion behavior of the material [7]. However, the results reported in the literature are often controversial claiming that the same metric could both decrease and increase susceptibility to corrosion. For example, it was suggested that the decrease of the grain size can either decrease $[8,9]$ or increase $[10]$ the corrosion resistance of aluminum. In fact, depending on whether grains were equiaxed or columnar, corrosion rate would variably increase or decrease with grain refinement [7]. 
TABLE 1: Chemical composition (cc) of the aluminum alloy determined by ICPOES.

\begin{tabular}{lc}
\hline Metal & cc (wt.\%) \\
\hline $\mathrm{Fe}$ & 0.2500 \\
$\mathrm{Si}$ & 0.1071 \\
$\mathrm{Cr}$ & 0.0056 \\
$\mathrm{Cu}$ & 0.0558 \\
$\mathrm{Mn}$ & 0.0600 \\
$\mathrm{Mg}$ & 0.2200 \\
$\mathrm{Co}$ & 0.0002 \\
$\mathrm{Ni}$ & 0.0036 \\
$\mathrm{~Pb}$ & $<0.0001$ \\
$\mathrm{Ca}$ & 0.0014 \\
$\mathrm{Ti}$ & 0.0060 \\
$\mathrm{Zn}$ & 0.1660 \\
$\mathrm{Al}$ & balance \\
\hline
\end{tabular}

In previous works [11-13], we studied the effect of ECAP process on the microstructure evolution and the mechanical properties of a commercial aluminum containing a low volume fraction of $\alpha$-AlFeSi located essentially at the grain boundaries. X-ray diffraction (XRD) analysis showed an important broadening of the reflections of the alloy attributed mainly to grain refinement and lattice distortions. The grain refinement and the accumulation of dislocations generated by ECA pressing lead to a significant improvement of the mechanical properties in compression and tension tests [13]. The present work aims to investigate the effect of ECAP on corrosion behavior of the same material. The effects of grain refinement and the $\alpha$-AlFeSi on the susceptibility to corrosion of aluminum alloy were especially discussed. This allows gaining a more detailed insight into the effect of SPD through ECAP on corrosion behavior of aluminum alloys. The results obtained for the ultrafine grained (UFG) aluminum alloy were compared with those of the coarse grained counterpart.

\section{Experimental Procedure}

2.1. Sample Preparation. The experiments were carried out using low purity aluminum (99.1\%). The material was received in the form of cast ingots. It was analysed by Inductively Coupled Plasma Optical Emission Spectrometry (ICPOES). The chemical composition is given in Table 1 . The material was annealed for 24 hours at $500^{\circ} \mathrm{C}$ and quenched in iced water. Samples with dimensions $\sim 10 \times 10 \times 70 \mathrm{~mm}^{3}$ were cut for ECA pressing. The die used for ECA pressing has two square channels of $10 \times 10 \mathrm{~mm}^{2}$ cross sectional area intersecting at an angle $\Phi=90^{\circ}$. The arc of curvature at the outer point of the intersection of the two channels delineated an angle $\Psi=20^{\circ}$. According to the equation given by Iwahashi et al. [14], the total equivalent strain, $\varepsilon_{N}$, accumulated by $N$ passes through the die was equal to $\sim N$.

In the present work, repetitive pressings of the same sample were conducted, at room temperature, to achieve an equivalent strain up to $\sim 4$ without rotation of the sample between two successive passes (the so-called route A [15]).
2.2. Electrochemical Measurements. The electrochemical tests were conducted at room temperature in aerated stagnant $\mathrm{NaCl}$ solutions used as the corrosive medium at $\mathrm{pH}=6.4$. $\mathrm{NaCl}$ (Aldrich) was added to bidistilled water in required amounts to prepare solutions with concentrations varying between 0.15 and $0.9 \mathrm{M}$ (0.875 and 5.25 wt.\%, resp.).

The working electrodes used were cut from the central part of the ECA pressed ( $N=2$ and 4$)$ samples. The nonpressed $(N=0)$ aluminum alloy was also studied for comparison. Before each experiment, the working electrodes of cross-section $1 \mathrm{~cm}^{2}$ were mechanically polished with grinding paper up to 1000 grit to a mirror finish. The electrodes were then degreased with acetone, finally washed with bidistilled water, and dried in air. In order to avoid a prolonged exposure to atmosphere leading to oxide formation on the Al surface, the samples were tested immediately after drying. A Pt sheet was used as a counter electrode. The potential was measured against a saturated calomel electrode (SCE) as a reference. Potentiodynamic polarization curves, using a computerized potentiostat (Radiometer model VoltaLab 40) and Voltamaster 4 software, were performed by starting scanning electrode potential from an initial potential equal or below the open circuit potential (OCP) to an anodic potential of $0.3 \mathrm{~V}$ in 3.5 wt. $\% \mathrm{NaCl}$ solution at $\mathrm{pH}=6.4$. Electrochemical impedance spectroscopy (EIS) measurements were carried out at open circuit potential (OCP) using the same Voltamaster 4 software. A $10 \mathrm{mV}$ amplitude was applied to the electrodes under study at sweeping frequencies between $100 \mathrm{kHz}$ and $0.1 \mathrm{~Hz}$. Some experiments were repeated two or three times, and reproducibility was found to be satisfactory.

2.3. Weight Loss Tests. The weight loss tests were carried out at room temperature in $100 \mathrm{~mL}$ glass beakers containing 3.5 wt. $\% \mathrm{NaCl}$ solution at $\mathrm{pH}=6.4$. The polished and cleaned specimens were weighed and immersed for various time intervals. Once the interval time of immersion was finished, the samples were removed from the solution and cleaned with a $70 \mathrm{wt} \% \mathrm{HNO}_{3}$ solution [16], washed with acetone and weighed again. The above steps were repeated, and the mass loss in every interval was measured to evaluate the corrosion rate $\left(\mathrm{mg} \cdot \mathrm{cm}^{-2}\right)$ of the samples.

2.4. Surface Analysis. For X-ray diffraction (XRD), optical microscopy (OM), and scanning electron microscopy (SEM) investigations, specimens of $\sim 5 \times 5 \times 10 \mathrm{~mm}^{3}$ were cut from the central part of the tested ECA pressed $(N=$ 4 ) and unpressed $(N=0)$ samples. Their surfaces were electrolytically polished for $30 \mathrm{~min}$ at a temperature below $10^{\circ} \mathrm{C}$ under an operating voltage of $30 \mathrm{~V}$, using a mixture of $66 \%\left(\mathrm{CH}_{3} \mathrm{CO}\right)_{2} \mathrm{O}$ and $34 \% \mathrm{HClO}_{4}$. Added polishing in a $10 \%$ $\mathrm{H}_{2} \mathrm{SO}_{4}$ solution was used for OM under polarized light.

2.5. X-Ray Diffraction Analysis. XRD was carried out with a Philips X'PERT PRO diffractometer in step scanning mode using $\mathrm{Co}-\mathrm{K}_{\alpha}$ radiation. The XRD patterns were recorded at room temperature in scan rate of $2 \times 10^{-3} \mathrm{deg} / \mathrm{s}$ in the scanning range $2 \theta=20-155^{\circ}$. The exact position and the full-width at half maximum (FWHM) of each reflection 
was determined using X'PERT HighScore Plus software. A correction for the contribution from the instrumental effects to the experimental FWHM, $\beta_{\text {exp }}$, for each peak were obtained using the following expression [12]:

$$
\beta=\left(\left[\left(\beta^{2}\right)_{\exp }-\left(\beta^{2}\right)_{\text {ins }}\right]^{1 / 2} \times\left[\beta_{\exp }-\beta_{\text {ins }}\right]\right)^{1 / 2},
$$

where $\beta_{\text {ins }}$ is the instrumental FWHM which was determined using $\mathrm{NaCl}$ or the undeformed aluminum as a standard reference material.

The mean coherent crystalline domain size and strain $\varepsilon$ for each pass were calculated using the Halder-Wagner (HW) method [17]. In the HW method, which assumes a Voigt peak shape, the crystallite size, $D$, and the strain, $\xi$, are related to $\beta^{*}$ by the following expression:

$$
\left(\frac{\beta^{*}}{d^{*}}\right)^{2}=\left[\left(\frac{1}{D}\right) \times \frac{\beta}{\left(d^{*}\right)^{2}}\right]+\left(\frac{\xi}{2}\right)^{2} .
$$

From (2), the intercept of the plot of $\left(\beta^{*} / d^{*}\right)^{2}$ versus $\beta /\left(d^{*}\right)^{2}$ gives the value of the equivalent strain, and the slope gives the mean cell size.

The lattice parameter of the aluminum before and after ECA pressings was obtained from a linear regression analysis of the measured lattice parameter, $a_{\text {app }}$, obtained from each reflection, plotted against the Nilson-Reley function [18]:

$$
\mathrm{N}-\mathrm{R}=\frac{\cos ^{2} \theta / \sin \theta+\cos ^{2} \theta / \theta}{2},
$$

and extrapolated to $\mathrm{N}-\mathrm{R}=0$; that is, $2 \theta=180^{\circ}$.

Assuming that the dislocation density before ECAP deformation $\rho_{i}$ is significantly lower than the remaining dislocation density $\rho$ after $\operatorname{ECAP}\left(\rho_{i} \ll \rho\right), \rho$ could be calculated using the following equation $[19,20]$ :

$$
\rho=\frac{1}{D\left(y+b / \varepsilon_{N}\right)},
$$

where $D$ is the coherency length (cell size) provided by XRD, $\varepsilon_{N}(=1.07 \mathrm{~N})$ is the plastic strain introduced, $N$ is the number of ECAP passes, $b(=0.2867 \mathrm{~nm})$ is the Burgers vector of dislocation, and $y(=2 \mathrm{~nm})$ is the annihilation distance of dislocation [20].

\section{Experimental Results}

\subsection{Microstructure Investigation}

3.1.1. XRD Analysis. The XRD patterns of the unpressed sample $(N=0)$ and sample processed by $\operatorname{ECAP}(N=4)$ between $2 \theta=20$ and $155^{\circ}$ are given in Figure 1(a). Besides the fundamental reflections of the aluminum matrix, very fine reflections with low intensity, are observed (inset of Figure 1(a)). These reflections correspond to the presence of a second phase. In several AlFeSi commercial alloys, the phase present is usually denoted by $\alpha$-AlFeSi ( $\alpha$-phase). Possible chemistry of the phase is $\mathrm{Al}_{8} \mathrm{Fe}_{2} \mathrm{Si}, \mathrm{Al}_{12} \mathrm{Fe}_{3} \mathrm{Si}$, or
$\mathrm{Al}_{15} \mathrm{Fe}_{3} \mathrm{Si}_{2}$. It should be noted, however, that the iron-rich phases form in commercial purity aluminum alloys in two very different forms. First is the coarse $1-2 \mu \mathrm{m}$ "constituents" formed by eutectic solidification, at a spacing of the dendrite cell size set by the solidification rate. Depending on the particular $\mathrm{Fe} / \mathrm{Si}$ ratio and the casting rate, different phases may result, that is, the metastable $\mathrm{Al}_{6} \mathrm{Fe}$ or the $\alpha$-phase. Besides, there is a residual Fe content typically about $0.04 \mathrm{wt} \%$ left in solution after casting. This can be partially precipitated as the $\alpha$-phase during homogenization anneals especially at the temperature used in the present work, only $500^{\circ} \mathrm{C}$, or during low temperature anneals following deformation. These solid state precipitates (usually called dispersoids) are very fine $(0.1$ to $0.2 \mu \mathrm{m})$ particles. In this work, the $\mathrm{X}$ ray emission spectrometry by SEM showed the presence of $\mathrm{Al}, \mathrm{Fe}$, and $\mathrm{Si}$ in the precipitates. Therefore, the $\alpha$-phase is present in the aluminum alloy before deformation and persists during ECAP since reflections, with lower intensities, corresponding to this phase are still observed after ECAP (inset of Figure 1(a)).

After ECAP, a pronounced reflection broadening was observed (Figure 1(b)). This is due to grain refinement and enhanced lattice distortions of the processed samples. In addition, the $K \alpha_{2}$ reflection, which was well resolved for the nondeformed sample $(N=0)$, became scarcely visible after ECAP because of the reflection broadening. The cell size and the dislocation density evolutions during ECAP are given in Figure 2. An intensive grain refinement was observed after the ECAP process. In fact, the grain size reached $\sim 200 \mathrm{~nm}$ after the two first passes and slightly continued to decrease to attain $\sim 192 \mathrm{~nm}$ after four passes. The decrease of the cell size during ECAP was accompanied by a significant increase of the dislocation density. It should be noted that during severe plastic deformation such as ECAP, subgrain boundaries evolve in the grain structures [21] developing areas with coherent crystalline domain (cell structure) [22, 23]. The dislocations distribution may affect the size of these areas.

3.1.2. Microscopic Analysis. After annealing of the as-cast aluminum, at $500^{\circ} \mathrm{C}, \mathrm{OM}$ reveals that the microstructure was heterogeneous and consists of equiaxed coarse grains with an average size of $\sim 80 \mu \mathrm{m}$ and significantly coarser ones with an average grain size of about $500 \mu \mathrm{m}$, due to prolonged annealing (Figure 3).

The SEM analysis gives information about the resulting microstructure of the material before and after ECAP. Before ECAP, SEM observations show that the aluminum matrix contains precipitates located essentially at grain boundaries, even though some precipitates were also observed in the grain interior (Figures 4(a) and 4(b)). As demonstrated by XRD and X-ray emission spectrometry by SEM, these precipitates correspond to the $\alpha$-phase. After ECAP, a heterogeneous microstructure was obtained consisting of ultrafine equiaxed grains and elongated grains (Figures $4(\mathrm{c})$ and $4(\mathrm{~d})$ ). We showed in a previous work [13] that the presence of the $\alpha$-AlFeSi essentially at grain boundaries allowed to reveal 


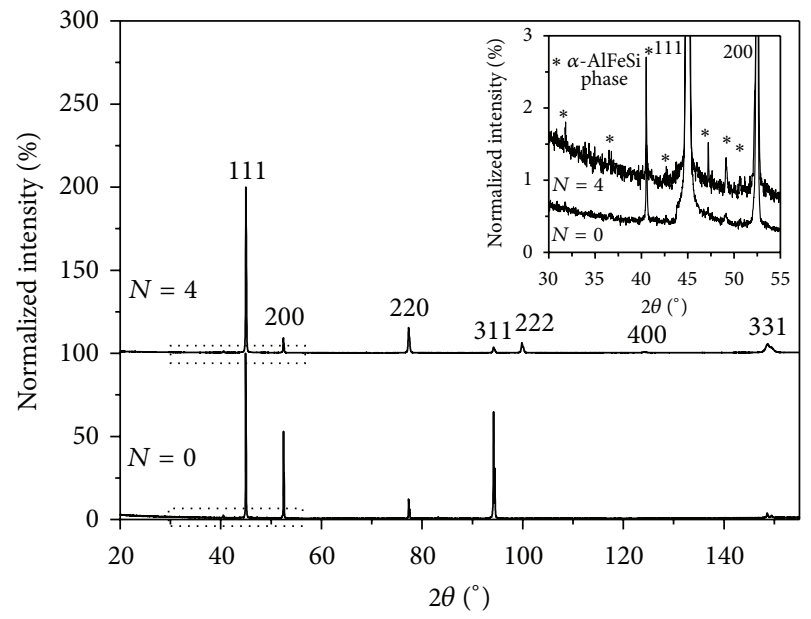

(a)

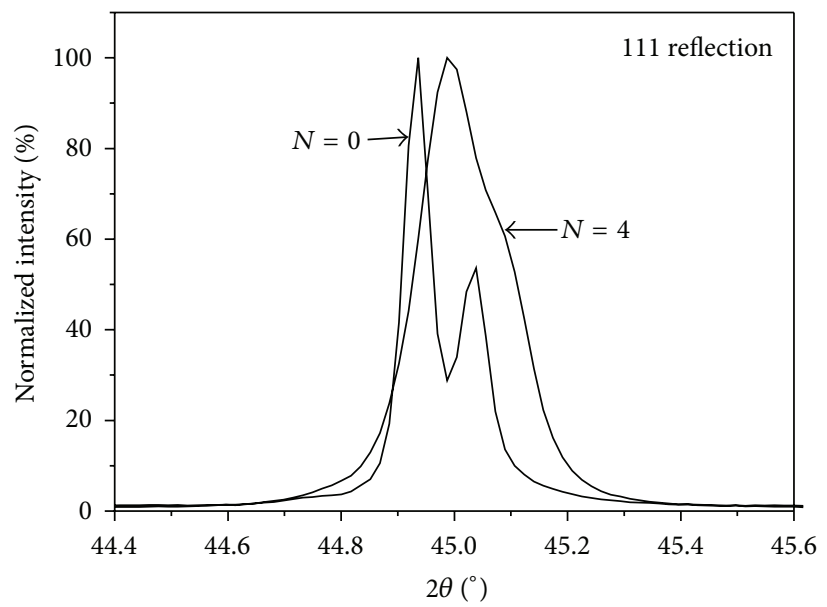

(b)

Figure 1: (a) X-ray diffraction pattern and (b) the 111 aluminum reflection of the nondeformed $(N=0)$ and deformed $(N=4)$ aluminium samples. Dashed rectangles are enlarged in the inset showing the $\alpha$-AlFeSi particles reflections.

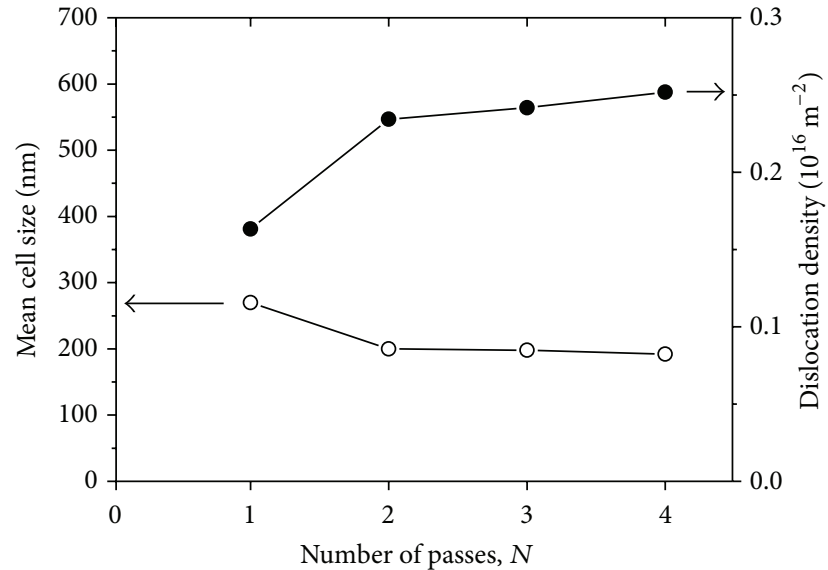

FIGURE 2: The cell size and the dislocation density evolutions during ECAP.

the initial shape of the grains and to follow their evolution during ECA pressing by OM; that is, the grains appeared to be elongated in the side face of the sample after ECAP. Therefore, ECAP leads to grain refinement of the aluminum alloy to some extent. Similar trend has been reported in microstructure investigation by transmission electron microscopy (TEM) on high purity aluminum processed by ECAP $[24,25]$.

In addition to grain refinement and enhanced dislocation density, high strain imposed by ECAP leads to the breakdown (Figure 4(e)) and/or partial dissolution of the $\alpha$-phase particles (Figure 4(f)).

3.2. Corrosion Behavior. When $\mathrm{Al}$ contacts with water solution, a rapid hydrated oxide film $(\mathrm{AlOOH}$, also regarded as

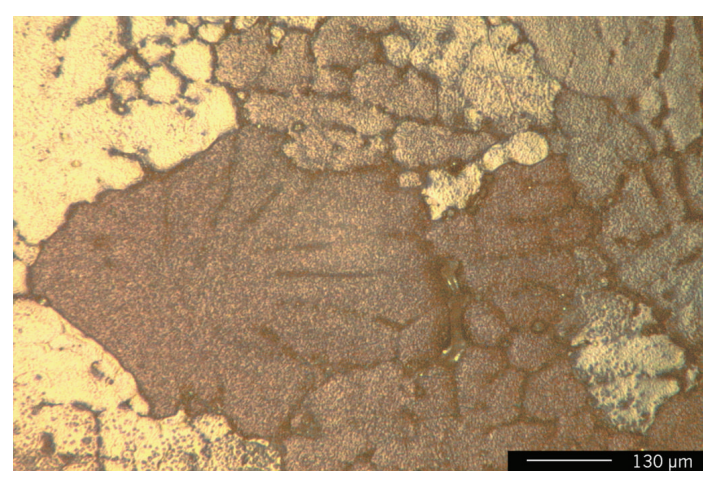

FIGURE 3: OM micrograph showing the microstructure of the nondeformed $(N=0)$ aluminium.

$\mathrm{Al}_{2} \mathrm{O}_{3} \cdot \mathrm{H}_{2} \mathrm{O}$ ) will form on the surface. The hydrated passive film formation process is as follows [26]:

$$
\begin{gathered}
\mathrm{Al}+\mathrm{H}_{2} \mathrm{O} \longrightarrow \mathrm{AlOH}+\mathrm{H}^{+}+\mathrm{e}^{-} \\
\mathrm{AlOH}+\mathrm{H}_{2} \mathrm{O} \longrightarrow \mathrm{Al}(\mathrm{OH})_{2}+\mathrm{H}^{+}+\mathrm{e}^{-} \\
\mathrm{Al}(\mathrm{OH})_{2}+\mathrm{H}_{2} \mathrm{O} \longrightarrow \mathrm{AlOOH}+\mathrm{H}^{+}+\mathrm{e}^{-}
\end{gathered}
$$

Then, the total electrode reaction is

$$
\mathrm{Al}+2 \mathrm{H}_{2} \mathrm{O} \longrightarrow \mathrm{AlOOH}+3 \mathrm{H}^{+}+3 \mathrm{e}^{-}
$$

In contact with $\mathrm{Cl}^{-}$containing solution, the film will be attacked, and the anodic dissolution products $(\mathrm{AlOHCl}$, $\mathrm{AlOHCl}_{2}$ ) having a good water solubility will promote the anodic dissolution of the passive film [27]. Figure 5 shows typical potentiodynamic polarization curves plotted from $-1.2 \mathrm{~V}$ to $0 \mathrm{~V}$ at $10 \mathrm{mV} / \mathrm{s}$ for the ECAP'ed $(N=2$ and $4)$ and unpressed $(N=0) \mathrm{Al}$ samples. All samples were immersed in a $3.5 \mathrm{wt} \%$ solution for about $3 \mathrm{~min}$ at $\mathrm{pH}=6.4$ 


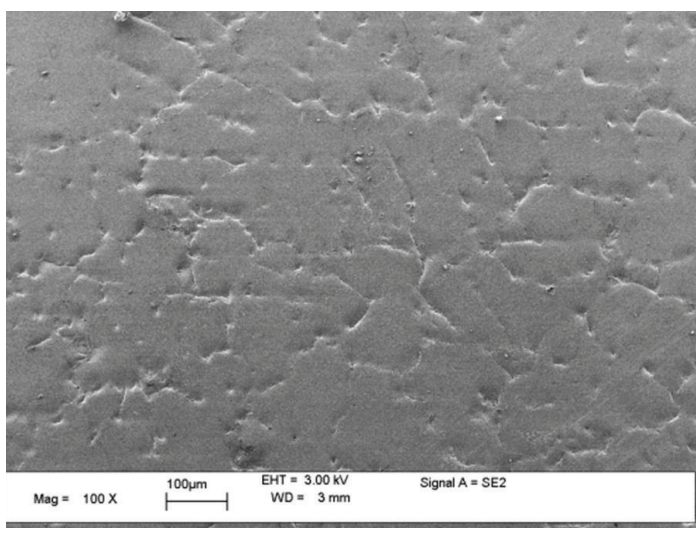

(a)

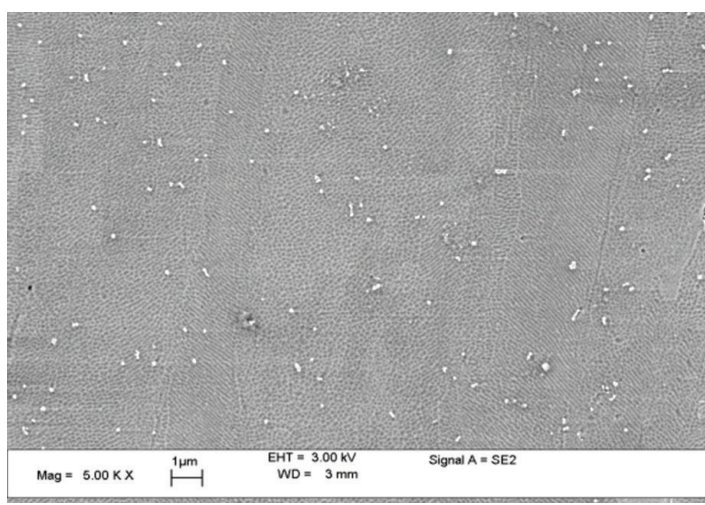

(c)

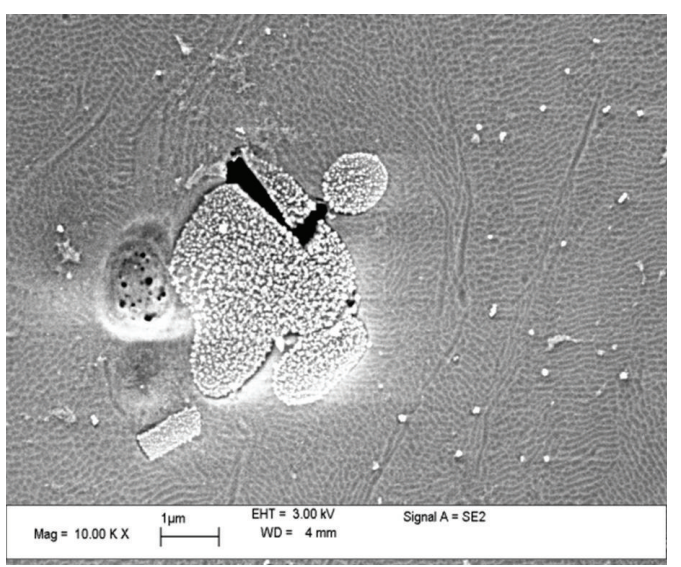

(e)

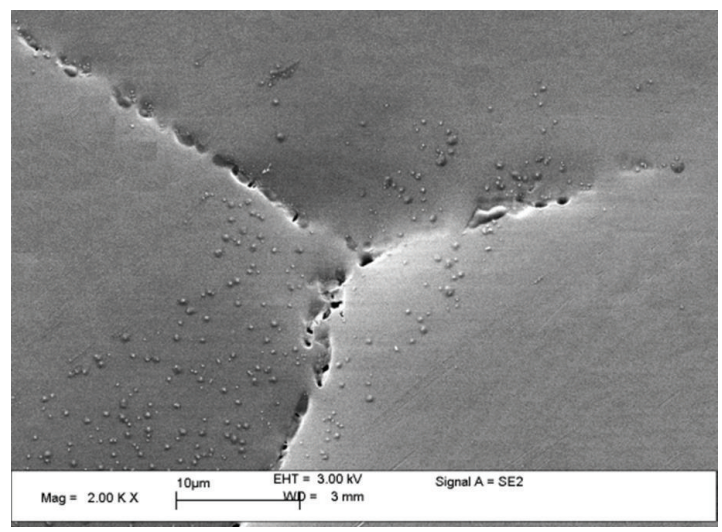

(b)

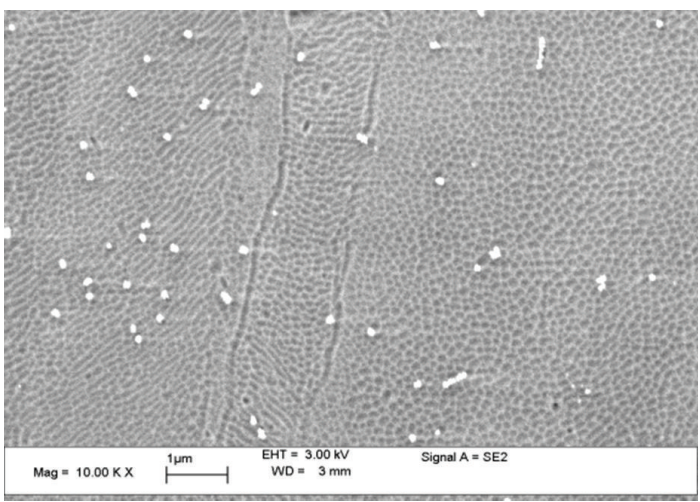

(d)

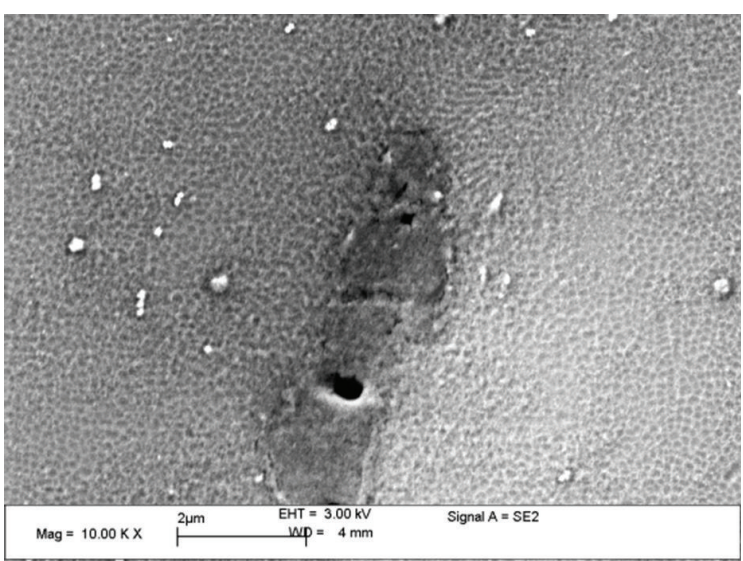

(f)

FIgURE 4: SEM micrographs with two magnifications showing the microstructure of $(\mathrm{a}, \mathrm{b})$ the nondeformed $(N=0)$ aluminium matrix containing $\alpha$-phase particles, (c, d) after ECAP $(N=4)$, and the effect of ECAP on the $\alpha$-phase particles, that is, (e) breakdown and (f) partial dissolution.

before polarization tests to achieve their stable OCP values. A similar shape is observed for the three samples. The more ECAP passes correlate with the nobler corrosion potentials and the higher corrosion current densities $\left(i_{\text {corr }}\right)$. In fact, corrosion current densities $\left(i_{\text {corr }}\right)$ of the unpressed $(N=0)$ and ECAP'ed samples $(N=2$ and 4$)$ are equal to about $8 \times 10^{-6}, 2 \times 10^{-5}$, and $4 \times 10^{-5} \mathrm{~A} / \mathrm{cm}^{2}$, respectively. The $i_{\text {corr }}$ values were determined, from the polarization curves, by extrapolation of the linear Tafel plots of the cathodic branches. The results show that the ECAP'ed Al sample $(N=4)$ has nobler corrosion potential value $\left(E_{\text {corr }}\right)$ but higher $i_{\text {corr }}$ and less corrosion resistance when compared with nondeformed $(N=0)$ and ECAP'ed $(N=2)$. Therefore, ECAP increased the susceptibility to corrosion of the aluminum alloy. While the value of $E_{\text {corr }}$ represents a thermodynamic characteristic of a given metal-electrolyte 


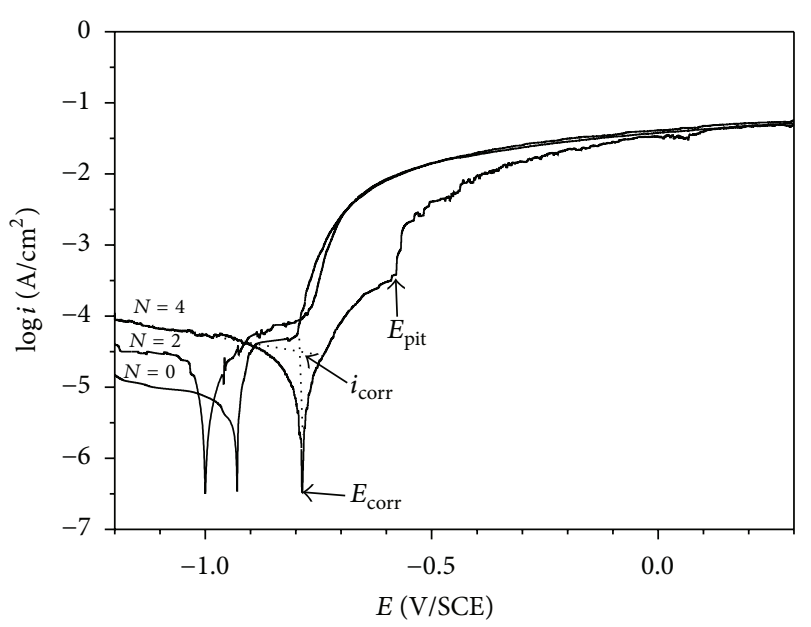

FIgURE 5: Potentiodynamic polarization curves obtained at $25^{\circ} \mathrm{C}$ and $10 \mathrm{mV} / \mathrm{s}$ with the nonpressed $(N=0)$ and ECAP'ed $(N=2$ and 4) samples in solution of $3.5 \mathrm{wt} . \% \mathrm{NaCl}$ solution at $\mathrm{pH} 6.4$.

system [28], the $i_{\text {corr }}$ value represents the kinetics of the metal corrosion and reflects more accurately the general corrosion rate than the value of $E_{\text {corr. }}$. It is important to note that $i_{\text {corr }}$ values of the ECAP'ed samples increased with increasing the ECAP number of passes, and the $i_{\text {corr }}$ after 4 passes is of several orders of magnitude higher than that obtained for the nondeformed $(N=0)$ sample.

Comparing the cathodic branches controlling the uniform corrosion process for all samples, it can be seen that, while the nondeformed sample shows low cathodic current density $i_{\text {cath }}$, the ECAP'ed sample $(N=4)$ exhibits the highest $i_{\text {cath }}$, which is equivalent to corrosion rate. During the positive potential scan, curves do not exhibit active dissolution region near $E_{\text {corr }}$. The lack of active dissolution could be assigned to the hydrated passive films formed on the $\mathrm{Al}$ samples. When the potential moves towards more anodic values, narrow anodic plateaus are observed for all samples, indicating formation of a passive layer on the electrode surface, and then the current rises rapidly, denoting destruction of this layer at a pitting potential $E_{\text {pit }}$ [29]. It is important to point out that, besides the higher $i_{\text {corr }}$ value, the current density of the passive layer increases, and its potential range decreases with ECAP, as a result of the decrease in pitting corrosion resistance for the ECAP'ed samples ( $N=2$ and 4$)$.

Figure 6(a) shows the impedance spectra on Nyquist plots obtained at open circuit potential (OCP) values from the ECAP'ed ( $N=2$ and 4$)$ and nondeformed $(N=0) \mathrm{Al} \mathrm{sam-}$ ples. For all samples, the results of EIS measurements showed that the diameter of the arc, giving the polarization resistance $\left(R_{p}\right)$, exceeds $5 \mathrm{k} \Omega \cdot \mathrm{cm}^{2}$. High $R_{p}$ values indicate that the aluminum forms a relatively stable oxide layer and has an excellent corrosion resistance in the naturally aerated $3.5 \mathrm{wt} \%$ $\mathrm{NaCl}$ solution. Compared with that of the unpressed sample, the $R_{p}$ value decreased with increasing ECAP passes; that is, the corrosion resistance decreased with increasing ECAP passes. The adopted Randles equivalent circuit, which is very common for these plots, is illustrated in Figure 6(b). It shows

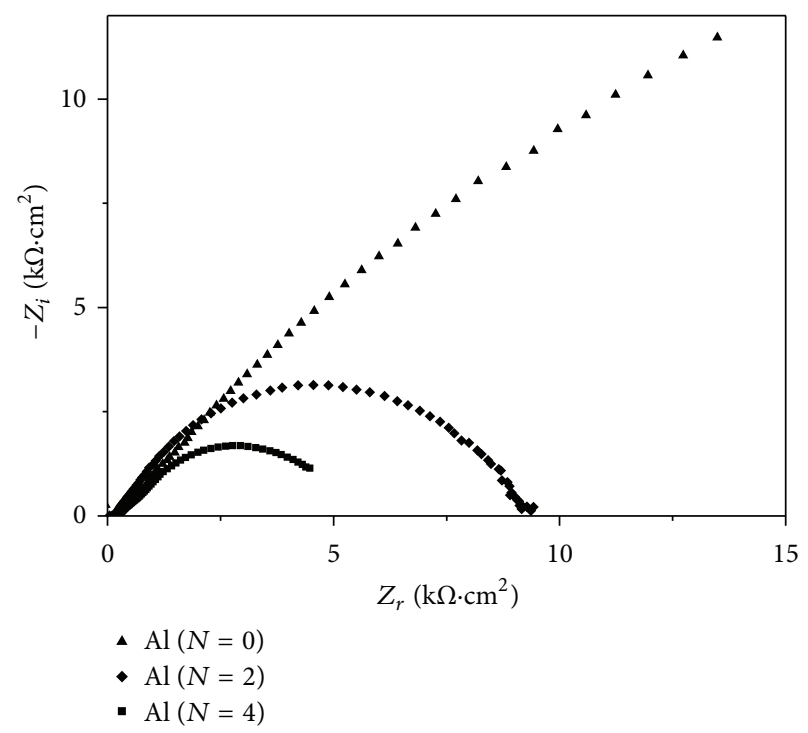

(a)

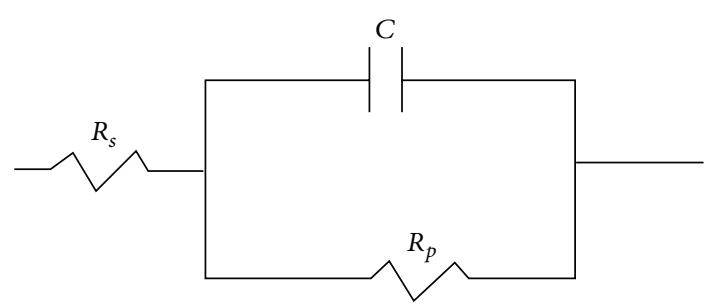

(b)

FIGURE 6: Impedance spectra of the ECAP'ed samples and unpressed sample obtained at open circuit (a) and $25^{\circ} \mathrm{C}$ in solution of $3.5 \mathrm{wt} . \%$ $\mathrm{NaCl}$ solution at $\mathrm{pH} 6.4$ and the electrical equivalent circuit (b).

the electrochemical system of metal/oxide layer/electrolyte, where $R_{s}, R_{p}$, and $C$ represent the electrolyte resistance, the charge-transfer resistance of corrosion reaction and the interfacial capacitance, respectively. This capacitance contains the contribution of the passive film $C_{f}$ and the double layer $C_{\mathrm{dl}}$, which are in series. The results of EIS measurements are consistent with those of the Tafel plots since $i_{\text {corr }}$ is inversely proportional to $R_{p}$ and can be obtained from $R_{p}$ via the SternGeary equation [30] given as

$$
i_{\text {corr }}=\frac{\beta_{a} \beta_{c}}{2.3\left(\beta_{a}+\beta_{c}\right) R_{p}},
$$

where $i_{\text {corr }}$ is the corrosion current density, $\beta_{a}$ and $\beta_{c}$ are the anodic and cathodic Tafel coefficients, respectively, and $R_{p}$ is the polarization resistance. The Tafel coefficients are generated from the anodic and cathodic branches of the Tafel plots.

The influence of scan rate, $v$ (in the range $5-100 \mathrm{mV} \cdot \mathrm{s}^{-1}$ ), on the potentiodynamic polarization behavior of the unpressed and ECAP'ed samples has been studied in $3.5 \mathrm{wt} . \%$ $\mathrm{NaCl}$ solution and $\mathrm{pH} 6.4$ (data obtained are not shown herein). It has been shown that the increase in $v$ shifts $E_{\text {pit }}$, in all cases, towards more noble values. The variation of $E_{\text {pit }}$ with $\log v$, for the unpressed and ECAP'ed samples, is 


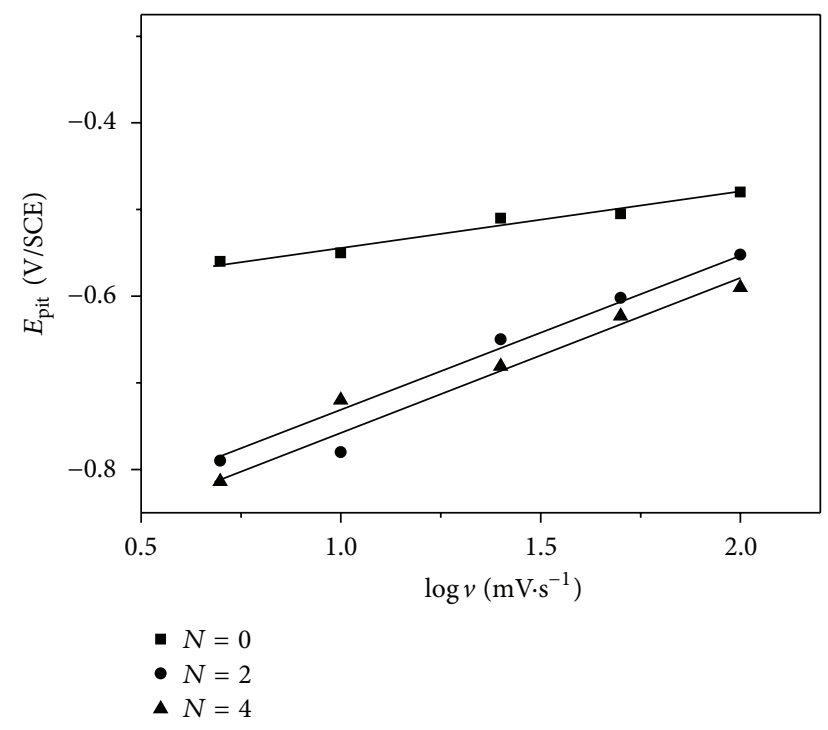

FIGURE 7: Dependence of $E_{\text {pit }}$ on the logarithm of scan rate $(\log v)$ for the ECAP'ed $(N=2$ and 4$)$ and unpressed $(N=0)$ samples, obtained at $25^{\circ} \mathrm{C}$ in $3.5 \mathrm{wt} . \% \mathrm{NaCl}$ solution at $\mathrm{pH} 6.4$.

depicted in Figure 7. A linear relationship is obtained fitting the relation

$$
E_{\mathrm{pit}}=a+b \log v,
$$

where $a$ and $b$ are constants depending on whether the sample was pressed or not. Similar results were obtained for $\mathrm{Zn} \mathrm{[31],} \mathrm{pure} \mathrm{Al,} \mathrm{and} \mathrm{Al}-\mathrm{Cu}$ alloys [32]. The linear trend has been explained in terms of incubation time (the time needed for $\mathrm{Cl}^{-}$ions to penetrate the passive film and to reach the metal surface) $[33,34]$. At high scan rate, initiation of passivity breakdown occurs only at more positive potentials corresponding to a sufficient short pit incubation time. For all samples, the increase of the scan rate up to $100 \mathrm{mV} \cdot \mathrm{s}^{-1}$ leads to the increase of the pitting potential. It is easy to note that $E_{\text {pit }}$ increases for all samples in the following order: 4 passes sample $<2$ passes sample $<$ nondeformed sample; that is, the pitting corrosion resistance decreases with increasing the ECAP passes.

Typical polarization curves of the ECAP'ed sample $(N=$ 2) in different $\mathrm{NaCl}$ concentrations at $\mathrm{pH}=6.4$ and scan rate of $10 \mathrm{mV} \cdot \mathrm{s}^{-1}$ in the anodic potential domain are shown in Figure 8(a). The curves show that an increase in the chloride concentration produces changes in both the anodic current density and the pitting potential $E_{\text {pit }}$ of the sample. Figure 8 (b) shows, for the unpressed and ECAP'ed samples, the relation between $E_{\text {pit }}$ and logarithm of $\mathrm{Cl}^{-}$concentration $\left(\log \left[\mathrm{Cl}^{-}\right]\right)$; straight lines are observed, fitting the following equation:

$$
E_{\text {pit }}=c-d \log \left[\mathrm{Cl}^{-}\right],
$$

where $c$ and $d$ are constants depending on whether the sample was pressed or not. The linear dependence is well established for pure $\mathrm{Al} \mathrm{[35]} \mathrm{and} \mathrm{is} \mathrm{entirely} \mathrm{due} \mathrm{to} \mathrm{the} \mathrm{variation} \mathrm{of} \mathrm{the}$ solution ohmic drop IR at the pit mouth. These results show

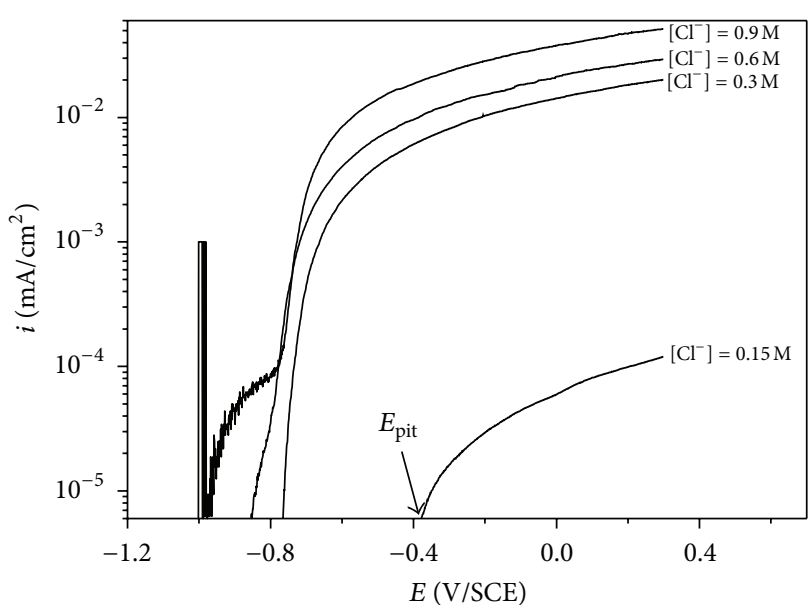

(a)

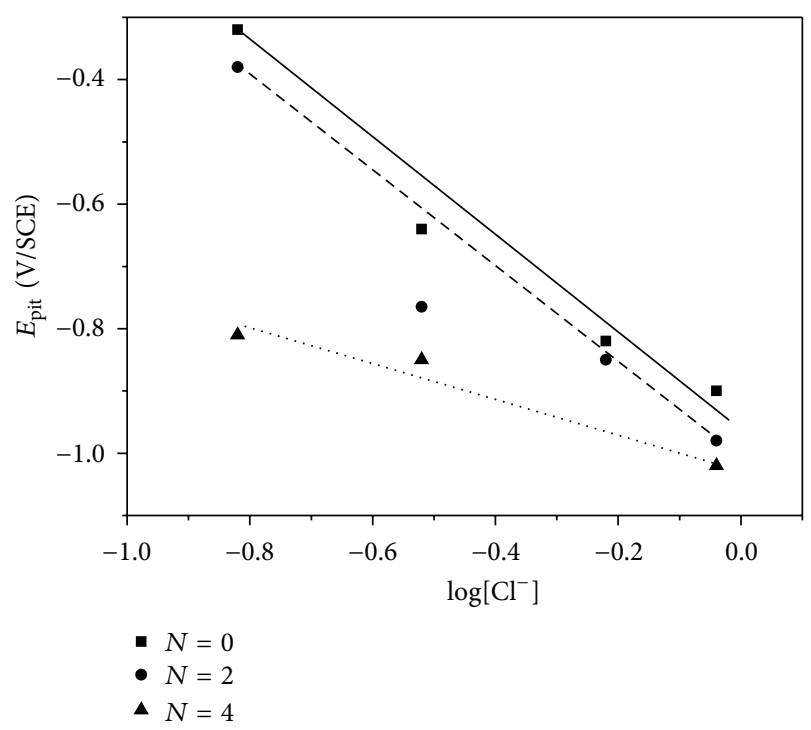

(b)

Figure 8: Polarization curves of the ECAP'ed sample $(N=2)$ in different $\mathrm{NaCl}$ concentrations at $\mathrm{pH}=6.4,25^{\circ} \mathrm{C}$, scan rate of $10 \mathrm{mV} \cdot \mathrm{s}^{-1}$ (a), and evolution of $E_{\mathrm{pit}}$ as a function $\log \left[\mathrm{Cl}^{-}\right]$for the nonpressed $(N=0)$ and ECAP'ed samples $(N=2$ and 4$)(b)$.

that the pitting corrosion depends on $\mathrm{NaCl}$ concentration. The increase of $\mathrm{NaCl}$ concentration leads to a decrease of the $E_{\text {pit }}$ to more negative values accounting for a decreased resistance to pitting corrosion. This resistance increases in the same order as for the effect of scan rate: 4 passes sample $<2$ passes sample $<$ nondeformed sample.

Figure 9 displays the corrosion rate variation with the immersion time during testing of the nondeformed and ECAP'ed samples. The corrosion rates of all samples increase with increasing immersion time or with increase of ECAP passes; that is, the 4 passes ECAP'ed sample has much higher corrosion rate than the nondeformed and 2 passes ECAP'ed samples. Also, it should be noted that the corrosion rate of the 4 passes sample is about 4 times higher than the nondeformed sample after immersion for 30 days. This confirms the above 


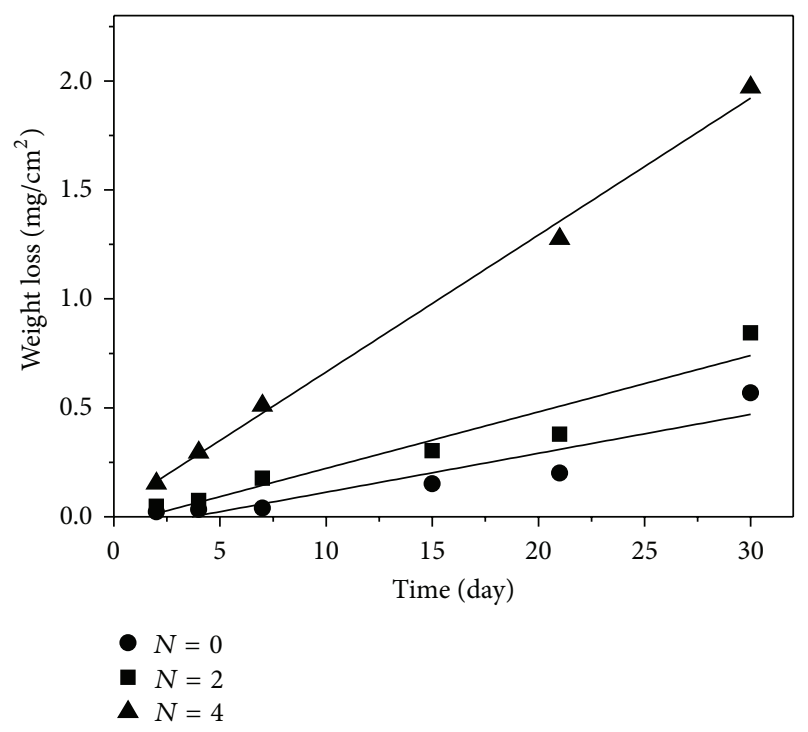

FIGURE 9: Corrosion rate variation with the immersion time of the nondeformed $(N=0)$ and ECAP'ed $(N=2$ and 4$)$, at $25^{\circ} \mathrm{C}$ in 3.5 wt. $\% \mathrm{NaCl}$ solution at $\mathrm{pH}=6.4$.

results indicating that ECAP leads to the decrease of the corrosion resistance of the aluminum alloy.

\section{Discussion}

The corrosion behavior of a commercial aluminum alloy processed by ECAP was investigated in $\mathrm{NaCl}$ solution using potentiodynamic polarization and immersion tests. Polarization curves showed that the increase of ECAP passes leads, in addition to the increase of weight loss, to higher corrosion current densities and a decrease of pitting corrosion resistance. Also, electrochemical impedance spectra (EIS) tests showed that the polarization resistance $\left(R_{p}\right)$ decreased with increasing ECAP passes. Therefore, corrosion resistance of the alloy remarkably diminished with increasing the ECAP number of passes. It is not easy to draw a clear conclusion about the reasons for this behavior since many contributions (grain refinement, internal stresses, second phase, etc.) should operate simultaneously. Previous works reported in the literature $[36,37]$ that grain refinement leads to a high density of grain boundaries which have higher energy than the bulk of the material. This enhances electron diffusion and leads to a more stable passive film and, therefore, to an enhanced corrosion resistance. Controversially, grain refinement may provide more sites to initiate corrosion which enhanced corrosion rate and consequently decreased corrosion resistance. Whether grain refinement is detrimental or not to corrosion resistance could be related to the material nature and environment [7]. It is clear from our results that the grain refinement of the ECAP'ed Al alloy to some extent was accompanied by increased susceptibility to corrosion.

It is well established that internal stresses, especially related to high dislocation accumulation generated by ECAP, may or may not result in the improvement of the corrosion resistance depending on the material [7].

ECAP leads to an intensive grain refinement accompanied by an increased dislocation density. For example, the remaining dislocation densities were equal to $0.25 \times 10^{16}$ and $0.26 \times 10^{16} \mathrm{~m}^{-2}$ for $N=2$ and 4 , respectively. The increase of the dislocation density with the number of ECAP passes could be one of the reasons for decreasing the corrosion resistance of the deformed $\mathrm{Al}$ alloy. This is in agreement with the results of Schultze et al. [38].

It is known that severe plastic deformation can lead to the quick decomposition of the Al-based supersaturated solid solution $[39,40]$. The start of the decomposition of supersaturated solid solution and formation of nanoprecipitates could be one of the reasons for decreasing the corrosion resistance. However, in the present work, the ECAP process leads to partial dissolution of the $\alpha$-phase. In fact, since there is a large volume of insoluble eutectic constituent present, the formation or dissolution of the $\alpha$-phase cannot be followed by observation of the $\alpha$-phase X-ray reflections. However, a very careful measurement of the aluminum lattice parameter can potentially detect changes in iron solute contents. Thus, a reflection shift to higher $2 \theta$ angles was observed after ECAP (Figure 1(b)) indicating the decrease of the aluminum lattice parameter during ECAP. For example, the lattice parameter values of the nondeformed $(N=0)$ and ECAP'ed $(N=4)$ samples are 4.05420 and $4.04957 \AA$, respectively, corresponding to a relative variation of about $-0.11 \%$. The decrease of the lattice parameter is due to partial dissolution of the $\alpha$-phase precipitates since the dissolution of $\mathrm{Fe}$ and $\mathrm{Si}$ in aluminum matrix decreases the lattice parameter. Indeed, the relative variations of the lattice parameter, $a$, with the concentration, $c$, of both Fe and Si, 1/a $(\Delta a / \Delta c)$, are -13.6 [41] and $-2.6 \%$ [42], respectively. The partial dissolution of the $\alpha$-phase was experimentally supported by SEM investigation (Figure 4(f)). It should be noted that, besides $\alpha$-phase dissolution, oriented strain introduced by the ECAP process could affect the lattice parameter value.

SEM examinations were carried out before and after immersing the nondeformed $(N=0)$ and ECAP'ed $(N=$ 4) $\mathrm{Al}$ samples in $3.5 \mathrm{wt} . \% \mathrm{NaCl}$ solution at $\mathrm{pH} 6.4$ for 30 days. The SEM micrographs (Figures 10(a) and 10(b)) show obvious localized corrosion damage, particularly on 4 passes ECAP'ed sample. Figure 10(a) exhibits relatively small and hemispherical pits with different sizes, grown throughout the surface of the nondeformed sample. Severity of pitting attack is enhanced by ECAP process, which produces, in particular after 4 passes, much larger $(\sim 0.5 \mu \mathrm{m})$ and deeper rectangular pits. SEM micrograph of Figure 10(c) shows that the $\alpha$-phase particles are the pit initiation sites. So, this attack takes place at the contact between the particles and the $\mathrm{Al}$ matrix. In the present work, susceptibility to corrosion results from local galvanic cells formed between the $\alpha$-phase particles and the aluminum matrix. These particles act as cathodes which allowed the reduction of oxygen and drive anodic dissolution of the surrounding matrix. The particles were broken down with the ECAP passes (Figure 4(e)). Consequently, the number of the galvanic cells increases and 


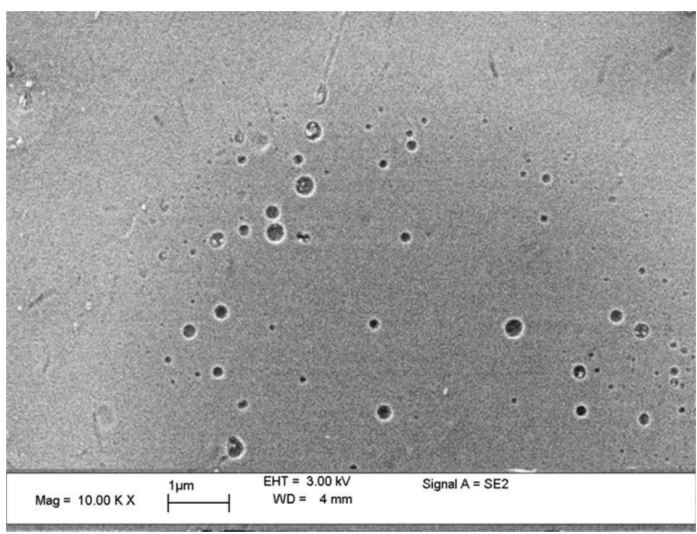

(a)

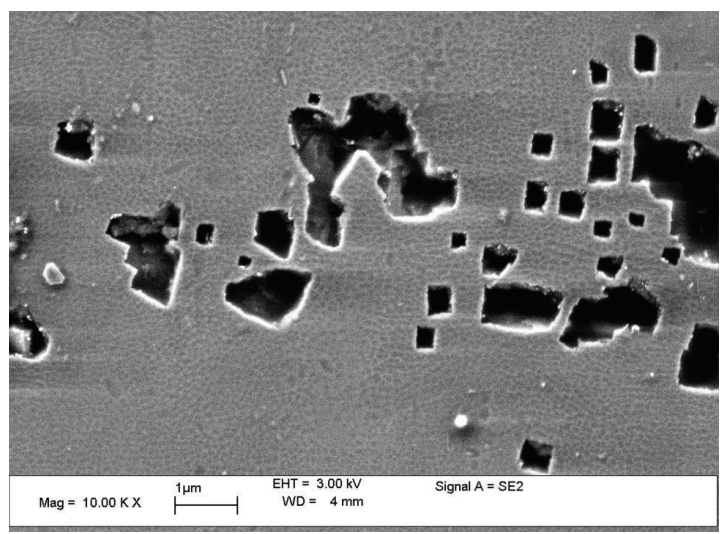

(b)

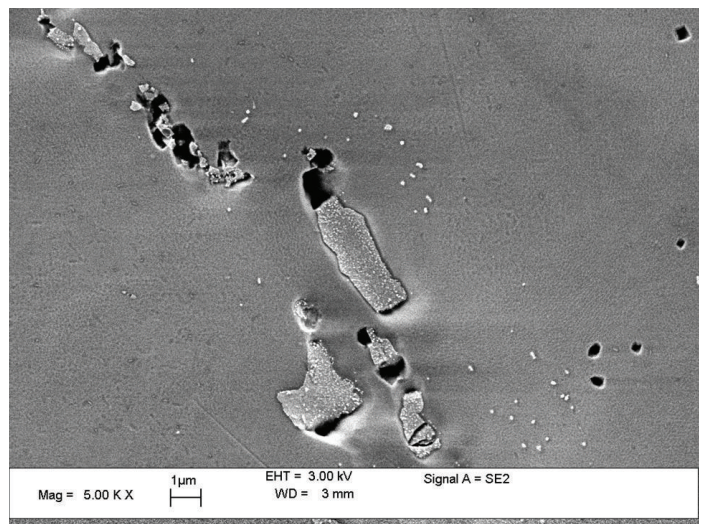

(c)

Figure 10: SEM micrographs of the nondeformed $(N=0)(\mathrm{a})$ and ECAP'ed $(N=4)(\mathrm{b})$ samples and the $\alpha$-phase particles which are the pit initiation sites (c).

so is the contact surface between the broken particles and the aluminum matrix. This leads to enhanced dissolution of the matrix which explains the decrease of the corrosion resistance of the aluminum alloy with ECAP passes. This is in agreement with the reported results of Wei et al. [43], which showed that the fragmentation of second phase particles improved localized corrosion behavior in Al-Mn alloys processed by accumulative roll bonding (ARB). Naeini et al. [44] studied the pitting corrosion susceptibility of ultrafine grained 5052 $\mathrm{Al}$ alloy (AA 5052) sheets deformed by ARB. They showed that as the ARB number of passes increased, intermetallic $\mathrm{Mg}$ and Fe-rich particles were refined so their total surface area increased. Thus, the preferential sites for initiation of pitting corrosion increased. In contrast, Song et al. [45] found that the refinement of Si containing impurities in pure aluminum processed by ECAP reduced the susceptibility of pitting corrosion which is consistent with the 'small cathode, large anode' mechanism. Comparable results for AA 1050 aluminum alloy deformed by ECAP have been previously reported [46]. It should be noted that a critical size of particles exists in aluminum alloys below which the particles cannot act as distinct electrochemical entities [47]. For $\mathrm{Al}-\mathrm{Cu}-\mathrm{Mg}$ alloys, this critical size varied between 3 and $8 \mathrm{~nm}$. For the $1100 \mathrm{Al}$ alloy, the particles size was largely higher. Accordingly, it is not possible that a stable protective passive oxide film forms.

\section{Conclusion}

The effect of ECAP process on the corrosion behavior of a commercial aluminum alloy was investigated in $\mathrm{NaCl}$ solution using potentiodynamic polarization and immersion tests. The alloy contains a low volume fraction of $\alpha$ $\mathrm{AlFeSi}$. ECAP leads to an intensive grain refinement of the aluminum alloy to the submicrometer level accompanied by an increased dislocation density. All electrochemical tests confirm that ECAP leads to a significant decrease of the corrosion resistance of the alloy: (i) potentiodynamic curves showed that the more ECAP passes correlate with the higher corrosion current densities and the decrease of pitting corrosion resistance; (ii) electrochemical impedance spectra (EIS) tests showed that the polarization resistance $\left(R_{p}\right)$ decreased with increasing ECAP passes; (iii) increase of scan rate and $\mathrm{NaCl}$ concentration leads to an increase and a decrease of $E_{\text {pit }}$ to more positive and negative potentials, respectively. The increase of susceptibility to corrosion results from local galvanic cells formed between the $\alpha$-AlFeSi and the aluminum matrix. The $\alpha$-phase particles act as cathodes 
which allowed the reduction of oxygen and drive anodic dissolution of the surrounding matrix. The particles were broken down with the ECAP passes which increase the number of the galvanic cells. This leads to enhanced dissolution of the matrix which explains the decrease of the corrosion resistance of the aluminum alloy with ECAP passes.

\section{Conflict of Interests}

The authors recognized that there is no conflict of interests concerning the results obtained.

\section{Acknowledgments}

The authors would like to acknowledge Professor N. Njah from the Laboratory of Applied Metallurgy, FSS (Tunisia), and Mr. N. Bouras from the University of Sétif (Algeria) for useful helps.

\section{References}

[1] V. I. Levit, R. I. Kuznetsov, N. A. Smirnova, V. P. Chernyshev, L. S. Davydova, and M. V. Degtyarev, "Tension of single crystals of KHN77TYUR alloy under hydrostatic-pressure up to 1 GPA," Fizika Metallov I Metaaovedene, vol. 59, no. 1, pp. 184-191, 1985.

[2] Y. Saito, N. Tsuji, H. Utsunomiya, T. Sakai, and R. G. Hong, "Ultra-fine grained bulk aluminum produced by accumulative roll-bonding (ARB) process," Scripta Materialia, vol. 39, no. 9, pp. 1221-1227, 1998.

[3] J. G. Brunner, N. Birbilis, K. D. Ralston, and S. Virtanen, "Impact of ultrafine-grained microstructure on the corrosion of aluminium alloy AA2024," Corrosion Science, vol. 57, pp. 209214, 2012.

[4] I. Son, H. Nakano, S. Oue, S. Kobayashi, H. Fukushima, and Z. Horita, "Effect of equal-channel angular pressing on pitting corrosion resistance of anodized aluminum-copper alloy," Transactions of Nonferrous Metals Society of China, English Edition, vol. 19, no. 4, pp. 904-908, 2009.

[5] M. Mabuchi and K. Higashi, "Mechanical properties of pure aluminium processed by equal channel angular extrusion," Journal of Materials Science Letters, vol. 17, no. 3, pp. 215-217, 1998.

[6] R. Z. Valiev and I. V. Alexandrov, "Nanostructured materials from severe plastic deformation," Nanostructured Materials, vol. 12, no. 1, pp. 35-40, 1999.

[7] K. D. Ralston and N. Birbilis, "Effect of grain size on corrosion: a review," Corrosion, vol. 66, no. 7, Article ID 075005, 13 pages, 2010.

[8] E. Kus, Z. Lee, S. Nutt, and F. Mansfeld, "A comparison of the corrosion behavior of nanocrystalline and conventional Al 5083 samples," Corrosion, vol. 62, no. 2, pp. 152-161, 2006.

[9] D. Song, A. Ma, J. Jiang, P. Lin, and D. Yang, "Corrosion behavior of ultra-fine grained industrial pure $\mathrm{Al}$ fabricated by ECAP," Transactions of Nonferrous Metals Society of China, English Edition, vol. 19, no. 5, pp. 1065-1070, 2009.

[10] T. S. Mahmoud, "Effect of friction stir processing on electrical conductivity and corrosion resistance of AA6063-T6 Al alloy," Proceedings of the Institution of Mechanical Engineers $C$, vol. 222, no. 7, pp. 1117-1123, 2008.

[11] A. Korchef, N. Njah, Y. Champion et al., "Material flow during equal channel angular pressing of aluminum containing
$\mathrm{Al}_{8} \mathrm{Fe}_{2}$ Si recipitates," Advanced Engineering Materials, vol. 6, no. 4, pp. 222-228, 2004.

[12] A. Korchef, Y. Champion, and N. Njah, "X-ray diffraction analysis of aluminium containing $\mathrm{Al}_{8} \mathrm{Fe}_{2} \mathrm{Si}$ processed by equal channel angular pressing," Journal of Alloys and Compounds, vol. 427, no. 1-2, pp. 176-182, 2007.

[13] A. Korchef, N. Njah, J. Masmoudi et al., "Evolution of the mechanical properties of aluminum containing $\mathrm{Al}_{8} \mathrm{Fe}_{2} \mathrm{Si}$ precipitates during equal channel angular pressing," Advanced Engineering Materials, vol. 6, no. 8, pp. 610-643, 2004.

[14] Y. Iwahashi, J. Wang, Z. Horita, M. Nemoto, and T. G. Langdon, "Principle of equal-channel angular pressing for the processing of ultra-fine grained materials," Scripta Materialia, vol. 35, no. 2, pp. 143-146, 1996.

[15] V. M. Segal, "Materials processing by simple shear," Materials Science and Engineering A, vol. 197, no. 2, pp. 157-164, 1995.

[16] B. Zaid, D. Saidi, A. Benzaid, and S. Hadji, "Effects of pH and chloride concentration on pitting corrosion of AA6061 aluminum alloy," Corrosion Science, vol. 50, no. 7, pp. 1841-1847, 2008.

[17] J. I. Langford, "A rapid method for analysing the breadths of diffraction and spectral lines using the Voigt function," Journal of Applied Crystallography, vol. 11, pp. 10-14, 1978.

[18] L. V. Azàroff and M. Buerger, The Powder Method, Mc GrowHill, New York, NY, USA, 1958.

[19] A. Rebhi, T. Makhlouf, N. Njah, Y. Champion, and J. Couzinié, "Characterization of aluminum processed by equal channel angular extrusion: effect of processing route," Materials Characterization, vol. 60, no. 12, pp. 1489-1495, 2009.

[20] L. Li, T. Ungár, Y. D. Wang et al., "Simultaneous reductions of dislocation and twin densities with grain growth during cold rolling in a nanocrystalline Ni-Fe alloy," Scripta Materialia, vol. 60 , no. 5, pp. 317-320, 2009.

[21] Y. Ito and Z. Horita, "Microstructural evolution in pure aluminum processed by high-pressure torsion," Materials Science and Engineering A, vol. 503, no. 1-2, pp. 32-36, 2009.

[22] R. Z. Valiev, R. K. Islamgaliev, and I. V. Alexandrov, "Bulk nanostructured materials from severe plastic deformation," Progress in Materials Science, vol. 45, no. 2, pp. 103-189, 2000.

[23] A. Zangiabadi and M. Kazeminezhad, "Development of a novel severe plastic deformation method for tubular materials: Tube Channel Pressing (TCP)," Materials Science and Engineering A, vol. 528, no. 15, pp. 5066-5072, 2011.

[24] Y. Iwahashi, Z. Horita, M. Nemoto, and T. G. Langdon, "An investigation of microstructural evolution during equalchannel angular pressing," Acta Materialia, vol. 45, no. 11, pp. 4733-4741, 1997.

[25] Y. Iwahashi, Z. Horita, M. Nemoto, and T. G. Langdon, "The process of grain refinement in equal-channel angular pressing," Acta Materialia, vol. 46, no. 9, pp. 3317-3331, 1998.

[26] J. D. Gorman, A. E. Hughes, D. Jamieson, and P. K. J. Paterson, "Oxide formation on aluminum alloys in boiling deionised water and $\mathrm{NaCl}, \mathrm{CeCl}_{3}$ and $\mathrm{CrCl}_{3}$ solutions," Corrosion Science, vol. 45, no. 6, pp. 1103-1124, 2003.

[27] Z. Szklarska-Smialowska, "Pitting corrosion of aluminum," Corrosion Science, vol. 49, no. 9, pp. 1743-1767, 1999.

[28] D. Song, A. Ma, J. Jiang, P. Lin, D. Yang, and J. Fan, "Corrosion behavior of equal-channel-angular-pressed pure magnesium in $\mathrm{NaCl}$ aqueous solution," Corrosion Science, vol. 52, no. 2, pp. 481-490, 2010. 
[29] A. Rucinskiene, G. Bilkulcius, I. Gudaviciùté, and E. Juzeliùnas, "Magnetic field effect on stainless steel corrosion in $\mathrm{FeCl}_{3}$ solution," Electrochemistry Communications, vol. 4, no. 1, pp. 86-91, 2002.

[30] W. S. Tait, An Introduction to Electrochemical Corrosion Testing for Practicing Engineers and Scientists, Pair O Docs, Racine, Wis, USA, 1994.

[31] S. S. Abd El Rehim, E. E. F. El-Sherbini, and M. A. Amin, "Pitting corrosion of zinc in alkaline medium by thiocyanate ions," Journal of Electroanalytical Chemistry, vol. 560, no. 2, pp. 175-182, 2003.

[32] M. A. Amin, S. S. Abd El Rehim, S. O. Moussa, and A. S. Ellithy, "Pitting corrosion of $\mathrm{Al}$ and $\mathrm{Al}-\mathrm{Cu}$ alloys by $\mathrm{ClO}_{4}{ }^{-}$ions in neutral sulphate solutions," Electrochimica Acta, vol. 53, no. 18, pp. 5644-5652, 2008.

[33] M. Metikas-Hukovic and I. NMilosev, "The effect of silicate ion on the corrosion of zinc powder in alkaline solutions," Journal of Applied Electrochemistry, vol. 22, pp. 448-455, 1992.

[34] H. Do Duc and P. Tissot, "Rotating disc and ring disc electrode studies of tin in neutral phosphate solution," Corrosion Science, vol. 19, no. 3, pp. 191-197, 1979.

[35] J. Soltis, N. J. Laycock, and D. Krouse, “Temperature dependence of the pitting potential of high purity aluminium in chloride containing solutions," Corrosion Science, vol. 53, no. 1, pp. 7-10, 2011.

[36] Y. H. Jang, S. S. Kim, C. D. Yim, C. Lee, and S. J. Kim, “Corrosion behaviour of friction stir welded AZ31B $\mathrm{Mg}$ in $3.5 \% \mathrm{NaCl}$ solution," Corrosion Engineering Science and Technology, vol. 42, no. 2, pp. 119-122, 2007.

[37] C. Op’t Hoog, N. Birbilis, and Y. Estrin, "Corrosion of pure $\mathrm{Mg}$ as a function of grain size and processing route," Advanced Engineering Materials, vol. 10, no. 6, pp. 579-582, 2008.

[38] J. W. Schultze, B. Davepon, F. Karman, C. Rosenkranz, A. Schreiber, and O. Voigt, "Corrosion and passivation in nanoscopic and microscopic dimensions: the influence of grains and grain boundaries," Corrosion Engineering Science and Technology, vol. 39, no. 1, pp. 45-52, 2004.

[39] B. B. Straumal, B. Baretzky, A. A. Mazilkin et al., "Formation of nanograined structure and decomposition of supersaturated solid solution during high pressure torsion of $\mathrm{Al}-\mathrm{Zn}$ and $\mathrm{Al}-\mathrm{Mg}$ alloys," Acta Materialia, vol. 52, no. 15, pp. 4469-4478, 2004.

[40] A. A. Mazilkin, B. B. Straumal, E. Rabkin et al., "Softening of nanostructured $\mathrm{Al}-\mathrm{Zn}$ and $\mathrm{Al}-\mathrm{Mg}$ alloys after severe plastic deformation," Acta Materialia, vol. 54, no. 15, pp. 3933-3939, 2006.

[41] J. Blétry, "Effets de taille dans les solutions solides de l'aluminium avec les métaux de transition de la première série," Journal of Physics and Chemistry of Solids, vol. 31, no. 6, pp. 12631272, 1970.

[42] S. K. Pabi, "Mechanism of the dissolution of Si in Al," Physica Status Solidi A, vol. 50, no. 1, pp. K9-K12, 1978.

[43] W. Wei, K. X. Wei, and Q. B. Du, "Corrosion and tensile behaviors of ultra-fine grained $\mathrm{Al}-\mathrm{Mn}$ alloy produced by accumulative roll bonding," Materials Science and Engineering A, vol. 454, pp. 536-541, 1995.

[44] M. F. Naeini, M. H. Shariat, and M. Eizadjou, "On the chlorideinduced pitting of ultra fine grains 5052 aluminum alloy produced by accumulative roll bonding process," Journal of Alloys and Compounds, vol. 509, no. 14, pp. 4696-4700, 2011.

[45] D. Song, A. B. Ma, J. H. Jiang, P. H. Lin, and J. Shi, "Improving corrosion resistance of pure $\mathrm{Al}$ through ECAP," Corrosion
Engineering Science and Technology, vol. 46, no. 4, pp. 505-512, 2011.

[46] M. Chung, Y. Choi, J. Kim, Y. Kim, and J. Lee, "Effect of the number of ECAP pass time on the electrochemical properties of $1050 \mathrm{Al}$ alloys," Materials Science and Engineering A, vol. 366, no. 2, pp. 282-291, 2004.

[47] K. D. Ralston, N. Birbilis, M. Weyland, and C. R. Hutchinson, "The effect of precipitate size on the yield strength-pitting corrosion correlation in $\mathrm{Al}-\mathrm{Cu}-\mathrm{Mg}$ alloys," Acta Materialia, vol. 58, no. 18, pp. 5941-5948, 2010. 

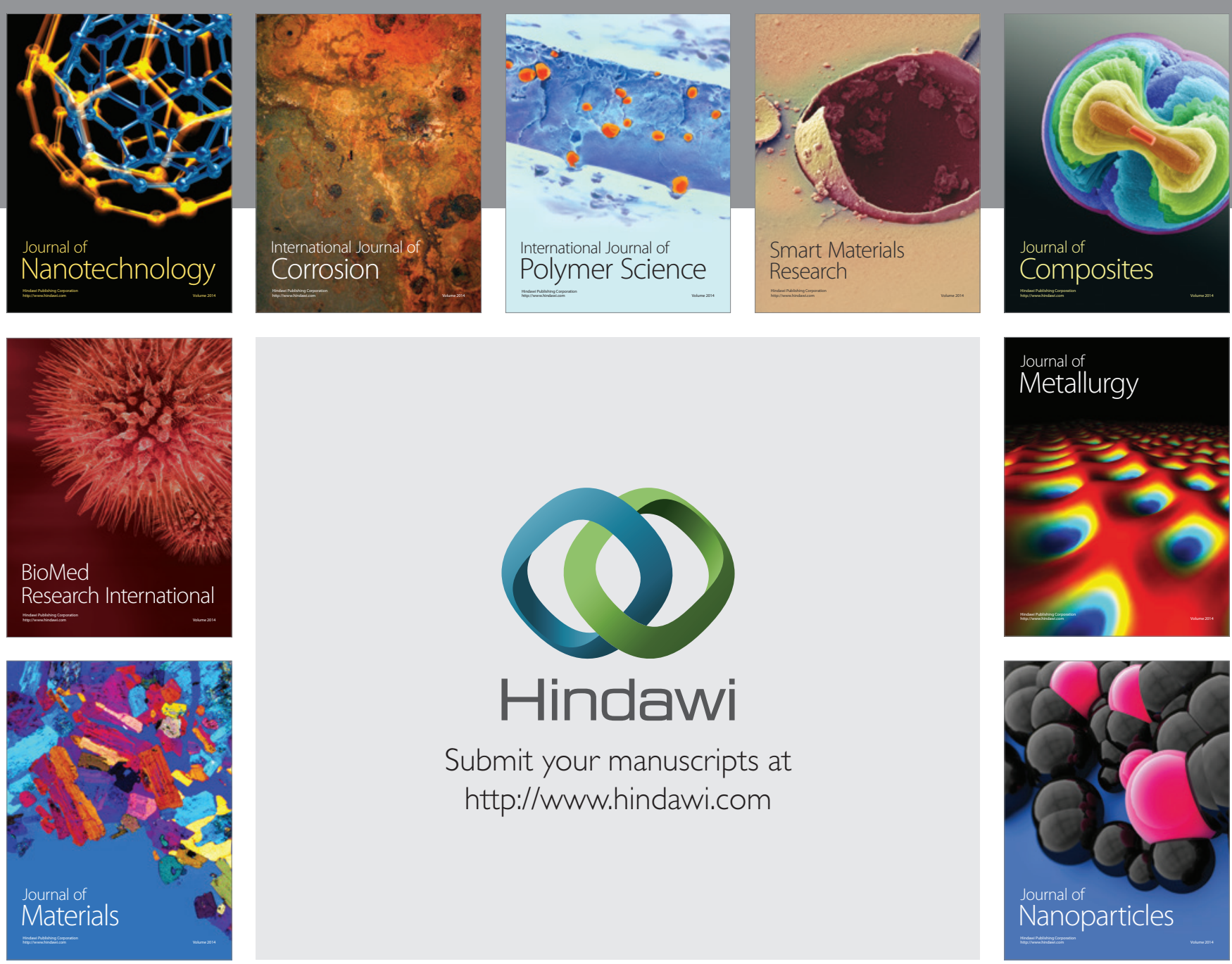

Submit your manuscripts at http://www.hindawi.com
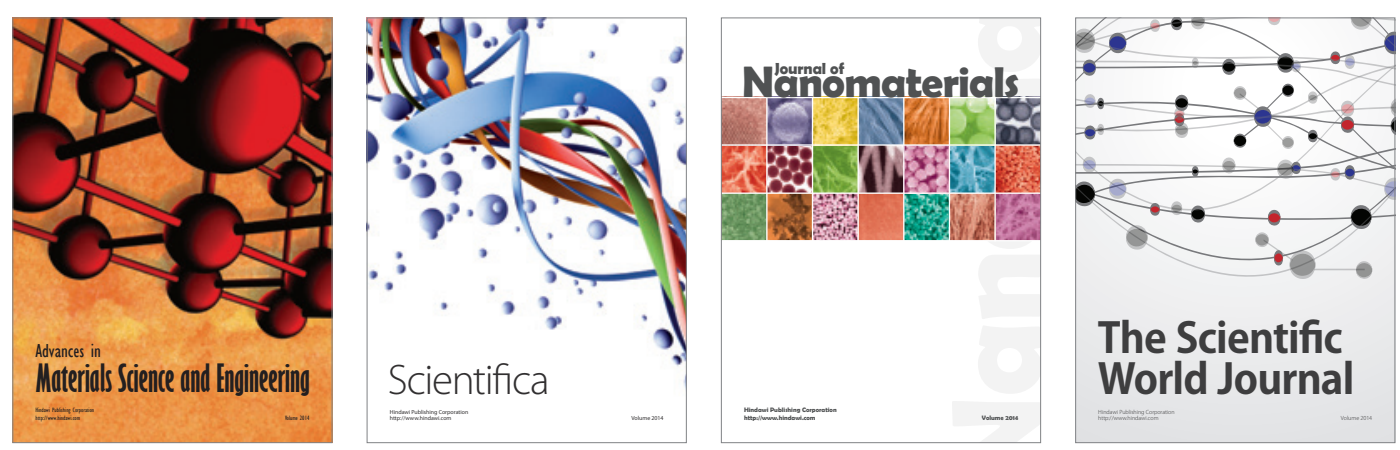

\section{The Scientific World Journal}
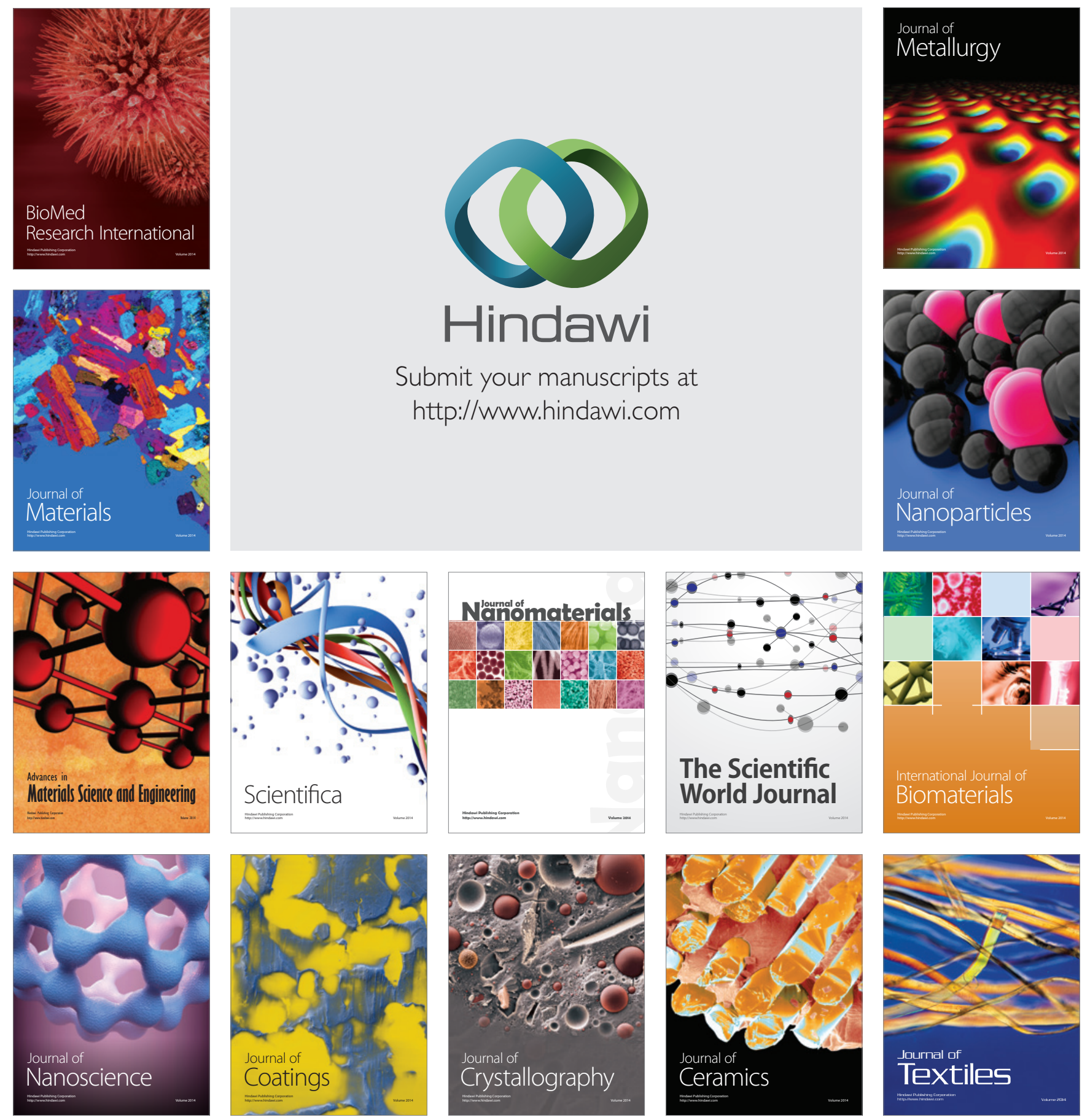